EVALUATION OF THE CATION EXCHANGE CAPACITY, CEC, OF NATURAL ZEOLITE OR OF ZEOLITE EXCHANGED WITH SODIUM FROM IGNIMBRITIC FORMATIONS IN PUNO, PERU, BY MEASURING THE REMOVAL OF AMMONIUM AND HEAVY METALS

\section{EVALUACIÓN DE LA CAPACIDAD DE INTERCAMBIO CATIÓNICO, CIC, DE ZEOLITA NATURAL O DE ZEOLITA INTERCAMBIADA CON SODIO DE FORMACIÓNES IGNIMBRÍTICAS EN PUNO, PERÚ, POR MEDICIÓN DE LA REMOCIÓN DE AMONIO Y DE METALES PESADOS}

Received 06112020

Accepted 06162020

Published 06302021

Vol. 38, No.2, pp. 95-103, May./Abr.2021

Revista Boliviana de Química

38(2), 95-103, May./Jun. 2021

Bolivian Journal of Chemistry

DOI : $10.34098 / 2078-3949.38 .2 .5$

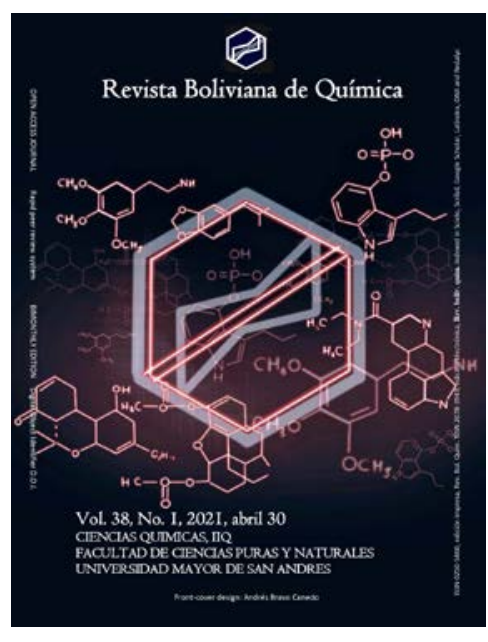

Peer-reviewed

Full original article

Marcelo Rodríguez Valdivia1,*, Edwin Urday Urday ${ }^{1}$, Gladys Ocharán Velásquez²

\begin{abstract}
${ }^{1}$ Escuela Profesional de Ingeniería de Materiales, Facultad de Ingeniería de Procesos FIP, Universidad Nacional San Agustín de Arequipa UNSA, Av. Independencia s/n-Pab. Ing. Materiales, phone +5154200037 , Arequipa, Perú, materiales@unsa.edu.pe, http://fip.unsa.edu.pe/ingmateriales/

${ }^{2}$ MyAP Microscopía Electrónica y Aplicaciones, Av. Rinconada del Lago 565, phone +51999453280, Lima, Perú
\end{abstract}

Keywords: Ignimbritic, Cation exchange capacity, Heulandite, Tertiary volcanism, Zeolite.

Palabras clave: Igminbrítico, Capacidad de intercambio, Heulandita, Vulcanismo terciario, Zeolita.

\title{
ABSTRACT
}

This paper presents the results of an investigation carried out on the ignimbritic formations in the Puno area in SE Peru, associated with the Tertiary volcanism. Mineralogical characterization, conducted by means of diffractometric analysis and scanning electron microscopy revealed the presence of heulandite together with smectite, quartz, mordenite, cristobalite and feldspar. Laboratory analysis carried out on representative samples of the investigated deposit, showed a cation exchange capacity (CEC) of about 50 meq per 100 grams of zeolitic material and a specific surface area, determined using the $\mathrm{N}_{2}$-BET method, of about $33.56 \mathrm{~m}^{2} / \mathrm{g}$.

Cation exchange capacity tests using solutions containing different concentrations of $\mathrm{NH}_{4}{ }^{+}, \mathrm{Pb}^{+2}, \mathrm{Cd}^{+2}, \mathrm{Cu}^{+2}$, $\mathrm{Zn}^{+2}$ and $\mathrm{Mn}^{+2}$, considered singly, have shown the following selectivity order: $\mathrm{Pb}^{+2}>\mathrm{Cd}^{+2}>\mathrm{Cu}^{+2}>\mathrm{Zn}^{+2}>\mathrm{Mn}^{+2}>\mathrm{NH}_{4}{ }^{+}$. Furthermore to increase cation exchange capacity, the zeolitic material was pretreated with a $2 \mathrm{~N} \mathrm{NaCl}$ solution. The results obtained demonstrated the efficiency of preconditioning that yields a substantial increase in exchange capacity for all the cations examined.

Downloadable from: Revista Boliviana 
Samples of water and superficial sediments were collected and the concentration of heavy metals (cadmium, zinc and arsenic) present in the samples was analyzed by means of induction coupled plasma atomic emission spectroscopy.

\section{*Correspondent author: mrodriquezv@unsa.edu.pe}

\section{RESUMEN}

Este artículo presenta los resultados de una investigación realizada sobre las formaciones ignimbríticas en el área de Puno en el sureste de Perú, asociadas con el volcanismo terciario. La caracterización mineralógica, realizada mediante análisis difractométrico y microscopía electrónica de barrido reveló la presencia de heulandita junto con esmectita, cuarzo, mordenita, cristobalita y feldespato. El análisis de laboratorio realizado en muestras representativas del depósito investigado mostró una capacidad de intercambio catiónico (CIC) de aproximadamente 50 meq por 100 gramos de material zeolítico y un área de superficie específica, determinada mediante el método $\mathrm{N}_{2}$-BET, de aproximadamente $33,56 \mathrm{~m}^{2} / \mathrm{g}$.

Las pruebas de capacidad de intercambio de cationes utilizando soluciones que contienen diferentes concentraciones de $\mathrm{NH}_{4}{ }^{+}, \mathrm{Pb}^{+2}, \mathrm{Cd}^{+2}, \mathrm{Cu}^{+2}, \mathrm{Zn}^{+2}$ y Mn${ }^{+2}$, consideradas individualmente, han mostrado el siguiente orden de selectividad: $\mathrm{Pb}^{+2}>\mathrm{Cd}^{+2}>\mathrm{Cu}^{+2}>\mathrm{Zn}^{+2}>\mathrm{Mn}^{+2}>\mathrm{NH}_{4}{ }^{+}$. Además, para aumentar la capacidad de intercambio catiónico, el material zeolítico se pre-trató con una solución de $\mathrm{NaCl} 2 \mathrm{~N}$. Los resultados obtenidos demuestran la eficiencia del preacondicionamiento que produce un aumento sustancial en la capacidad de intercambio para todos los cationes examinados.

\section{INTRODUCTION}

Traditionally the focus of Peru's mining industry, one of the mainstays of the country's economy, has been the extraction of copper, gold and other metal ores. However, Peru also offers unexplored potential in the industrial mineral sector. For some years now a research project has been exploring the possibility of industrially exploiting deposits containing feldspar, quartz, clay. Increasing attention is now being focused on industrial minerals, such as zeolites with high ion exchange capacity which are eco-friendly and inexpensive minerals, that find application in a variety of industrial sectors including waste water, gas and steam treatment, in agriculture, in animal feed, excreta and waste amendment. Due to the low cost and high efficiency in the removal of contaminants by adsorption, zeolites are widely used in wastewater treatment [1]. Natural zeolites show biological activities due to the ease adsorption and cation exchange. For this reason they are used in medicinal and pharmaceutical processes [2]. In [3] it is concluded that zeolites can be used as a food additive due to their unique physical and chemical characteristics.

Heightened environmental awareness among governments and the public in general, calls for a greater commitment by industries and the extractive industry in particular, to reduce pollutant emissions. Pollution in mining areas, known to be associated chiefly with the presence of heavy metals, is caused both by acid mine drainage and by water infiltrating mine waste rock or tailings dumps leaching out the heavy metals contained therein. These elements are transported via runoff and redeposited in some cases at great distances from the pollution source. Thus mine drainage waters need to be treated, removing heavy metals via precipitation in suitable plants or by means of reactive barriers or filters that are able to adsorb the pollutants contained in the water thereby minimizing their diffusion into neighbouring areas. Wang [4] (cited by Ciosek [5, p. 10]), indicted that natural zeolites are abundant around the world and have been successfully used to solve environmental problems. One of its important properties is the ability to exchange dissolved cations in liquid solutions.

An investigation currently being carried out to address this important issue is aimed at assessing Peru's mining potential in terms of materials with high ion exchange capacity. This paper presents the first results of an investigation on the Tertiary ignimbritic formations in the Puno area in southern Peru. A mineralogical study carried out on a sample removed from this deposit, where prospection is underway, using diffractometric analysis, and scanning electron microscopy (SEM) revealed the presence of heulandite along with other adsorbent minerals. Technical properties were also determined including CEC, bulk density, specific surface area, and cation exchange capacity of the untreated Na-exchanged material towards $\mathrm{NH}_{4}{ }^{+}, \mathrm{Pb}^{+2}, \mathrm{Cd}^{+2}, \mathrm{Cu}^{+2}, \mathrm{Zn}^{+2}$ and $\mathrm{Mn}^{+2}$, singly or in combination. The results of the experimental investigation showed a good cation exchange capacity of the material examined especially towards heavy metals. Furthermore, pretreating the zeolite material with a $2 \mathrm{~N} \mathrm{NaCl}$ solution significantly enhanced 
Marcelo Rodríguez Valdivia et al. RBQ Vol.38, No.2, pp. 95-103, 2021

the exchange capacity toward all the cations examined. Kragovi [6] (cited by Shi [7, p.622], mentioned that the pretreated zeolite improves its adsorption capacity under certain conditions. It must be considered that in a natural zeolite there are pores clogged by the presence of impurities

\section{EXPERIMENTAL}

\section{Materials and methods}

\section{Material preparation}

The sample was reduced in size by open circuit primary crushing using a jaw crusher followed by secondary crushing in a roll crusher operating in closed circuit with a $5 \mathrm{~mm}$ screen. The crushed product was then classified by screening to $0.7 \mathrm{~mm}$.

In this way two size classes were obtained: $-5+0.7 \mathrm{~mm}$ and $-0.7 \mathrm{~mm}$ accounting for around $79 \%$ and $21 \%$ by weight of the total sample. At this stage of the experimental investigation only the $-5+0.7 \mathrm{~mm}$ size class was investigated to explore its potential use for the manufacture of filters for purifying contaminated water treating [8].

\section{Characterization}

Chemical and mineralogical composition of a sample of this material were determined using a Siemens D5000 diffractometer and LEO EVO 50VP scanning electron microscope (SEM) manufactured by Oxford Instruments equipped with an energy dispersive spectrometer (EDS) microanalyser. At this stage of the experimental investigation only the $-5+0.7 \mathrm{~mm}$ size class was investigated here to explore its potential use for the manufacture of filters for purifying contaminated water treating.

A Micromeritics Instruments AccuPyc 1330 gas pycnometer was used to determine specific gravity. By means of a Quantachrome Instrument Autosorb-1 automatic surface area and pore size analyser, specific surface area using the BET multipoint method and the following operating conditions; outgas temperature $=150{ }^{\circ} \mathrm{C}$; outgas time $=3$ hours; $\mathrm{P} / \mathrm{P}_{0}$ ranging from 0.05 to 0.3 (where $\mathrm{P}_{0}$ is the gas pressure used at the test temperature). Cation exchange capacity (CEC), was determined using the non-normalized double-ion exchange method $-1 \mathrm{~N}$ ammonium acetate solution and $10 \%$ potassium chloride solution - proposed by Minato

\section{Na-exchange zeolite}

Na-exchange was achieved by placing the zeolite sample in a vessel containing a $2 \mathrm{~N} \mathrm{NaCl}$ solution with solid-toliquid ratio of 1:4 and leaving at ambient temperature for 10 days modified from [9]. The material was then filtered and stove dried at around $40^{\circ} \mathrm{C}$.

\section{Reagents}

The starting solutions were prepared from the following salts: $\mathrm{NH}_{4} \mathrm{Cl}(99.5 \%), \mathrm{Pb}\left(\mathrm{CH}_{3} \mathrm{COO}\right)_{2} .3 \mathrm{H}_{2} \mathrm{O}(99.0 \%)$, $3 \mathrm{CdSO}_{4} \cdot 8 \mathrm{H}_{2} \mathrm{O}$ (98\%), $\mathrm{CuCl}_{2} \cdot 2 \mathrm{H}_{2} \mathrm{O}$ (99.09\%), $\mathrm{ZnCl}_{2}$ anhidro (97.0\%) and $\mathrm{MnCl}_{2} \cdot 4 \mathrm{H} 2 \mathrm{O}$ (99\%), were purchased from Carlo Erba, Italy.

\section{$\mathrm{NH}_{4}{ }^{+}, \mathrm{Pb}^{+2}, \mathrm{Cd}^{+2}, \mathrm{Cu}^{+2}, \mathrm{Zn}^{+2}$ and $\mathrm{Mn}^{+2}$ cation exchange tests}

Tests on both, the untreated as well as the Na-exchanged zeolite were carried out placing $5 \mathrm{~g}$ of the material ( $2 \mathrm{~g}$ for the tests with the $\mathrm{Pb}^{+2}$ cation) in flasks containing $150 \mathrm{~mL}$ solution and agitating at room temperature [10] on a New Brunswick Scientific G 24 environmental incubator shaker (150 rpm).

The calculated amount of cation uptake by the zeolite comes out from the difference between the amount in the starting and final solutions [11,12]. For the metal cations, chemical determinations were done using a spectrometer Perkin Elmer OPTIMA-2100-DV ICP [13,14]. Ammonia was determined using the standard distillation and titration procedure [15].

\section{$\mathrm{NH}_{4}{ }^{+}, \mathrm{Zn}^{+2}$ cation exchange tests varying time}

To determine the time required to attain equilibrium conditions preliminary ion exchange tests were performed on the $-5+0,7 \mathrm{~mm}$ untreated zeolite material following the procedures described above using solutions containing around $1000 \mathrm{mg} / \mathrm{L} \mathrm{NH}_{4}{ }^{+}$and $1000 \mathrm{mg} / \mathrm{L} \mathrm{Zn}^{+2}$ respectively. 
Marcelo Rodríguez Valdivia et al. RBQ Vol.38, No.2, pp. 95-103, 2021

\section{Tests by varying cation concentrations in the starting solution}

These tests were performed following the above described procedures and for a contact time of 24 hours on the untreated and Na-exchanged material and using solutions containing different cation concentrations, examined singly.

The correlation of experimental data with the Freundlich and Langmuir isotherms (Malamis [16], cited by Carbonel [17, p.263]), defines the adsorption isotherm as the equation or curve that, in equilibrium condition, relates the concentration of metal adsorbed in the solid phase with the concentration of metal in solution to a specific temperature. The experimental data were correlated using the models proposed by Freundlich and Langmuir:

The Freundlich adsorption isotherm model is given by Ec. (1)

$$
\mathrm{X}=\mathrm{k} \mathrm{Cf}^{\frac{1}{n}} \quad \text { Ec. }(1)
$$

where: $\mathrm{X}$ is the amount of cation exchanged per unit mass of zeolite (mg/g); Cf is the equilibrium cation concentration in solution (mg/L); $\mathrm{k}$ and $\mathrm{n}$ are constants [18].

The Langmuir adsorption isotherm model is given by Ec. (2)

$$
\mathrm{X}=\frac{\mathrm{Xmb} \mathrm{bf}}{(1+\mathrm{b} \mathrm{Cf})} \quad \text { Ec. }(2)
$$

where: $X$ is the amount of cation exchanged per unit mass of zeolite $(\mathrm{mg} / \mathrm{g}) ; \mathrm{X}_{\mathrm{m}}$ is the maximum amount of cation exchanged per unit mass of zeolite $(\mathrm{mg} / \mathrm{g}) ; \mathrm{C}_{\mathrm{f}}$ is the equilibrium cation concentration in solution (mg/L); $\mathrm{b}$ is Langmuir isotherm constant related with adsorption energy [18]. For the determination of adsorption isotherms, non-linear regression analysis was applied, trying to minimize the error between the estimated and experimental data [19].

\section{RESULTS AND DISCUSSION}

\section{Mineralogical and Physicochemical Characterization}

The analysis by X-ray diffractometer showed mineralogical phases such as; heulandite; mordenite; smectite; quartz; cristobalite and feldspar, evidencing a natural zeolite with the presence of impurities. Figure No. 1, shows the mineralogical species.

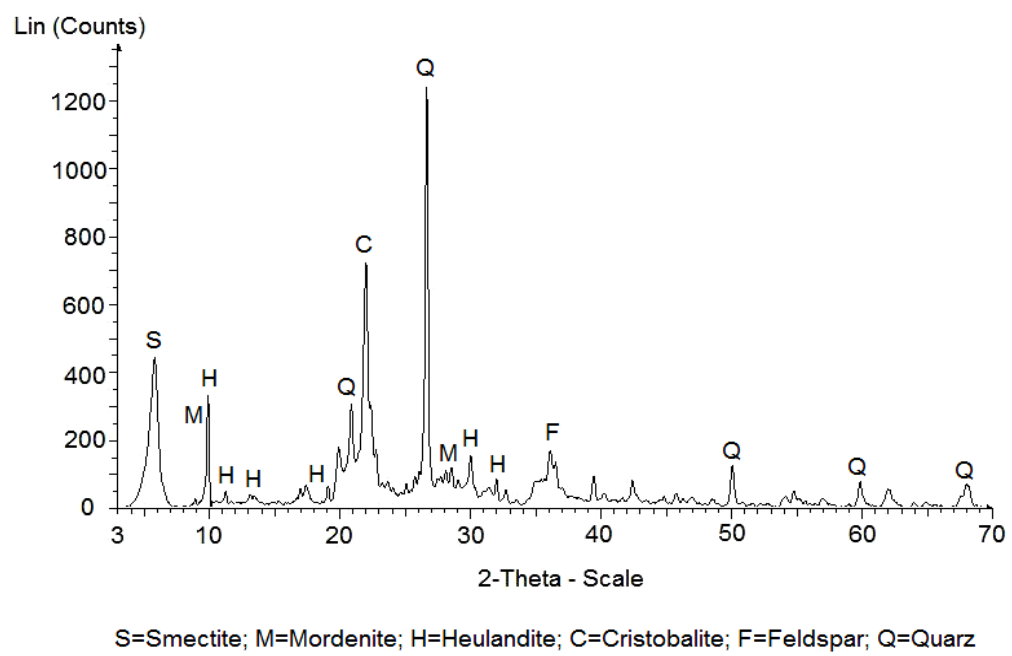

Figure No. 1. X-ray diffractogram showing the main mineralogical species present in samples

Figure No. 2 shows tabular structures of heulandite crystals with fibrous mordenite.

Downloadable from: Revista Boliviana 


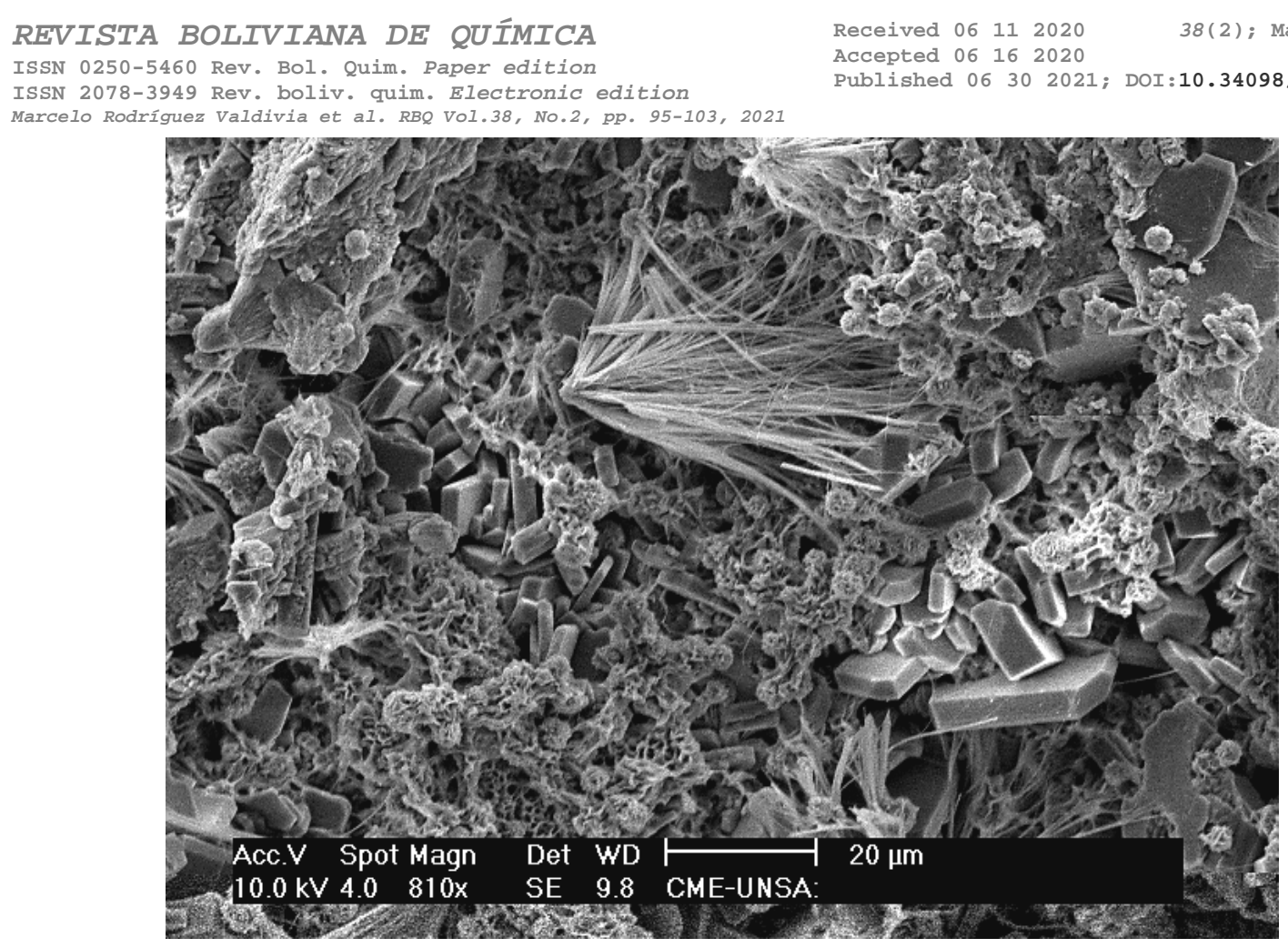

Figure No. 2. SEM micrograph showing heulandite and mordenite embedded in clay

Table No. 1, shows the chemical composition determined by X-ray analysis.

Table No. 1. Chemical composition of the as received material determined by means of X-ray spectrometry

\begin{tabular}{ccccccccccc}
\hline $\begin{array}{c}\text { L.O.I. } \\
{[\%]}\end{array}$ & $\begin{array}{c}\mathrm{Na}_{2} \mathrm{O} \\
{[\%]}\end{array}$ & $\begin{array}{c}\mathrm{MgO} \\
{[\%]}\end{array}$ & $\begin{array}{c}\mathrm{Al}_{2} \mathrm{O}_{3} \\
{[\%]}\end{array}$ & $\begin{array}{c}\mathrm{SiO}_{2} \\
{[\%]}\end{array}$ & $\begin{array}{c}\mathrm{P}_{2} \mathrm{O}_{5} \\
{[\%]}\end{array}$ & $\begin{array}{c}\mathrm{K}_{2} \mathrm{O} \\
{[\%]}\end{array}$ & $\begin{array}{c}\mathrm{CaO} \\
{[\%]}\end{array}$ & $\begin{array}{c}\mathrm{TiO}_{2} \\
{[\%]}\end{array}$ & $\begin{array}{c}\mathrm{MnO}^{2} \\
{[\%]}\end{array}$ & $\begin{array}{c}\mathrm{Fe}_{2} \mathrm{O}_{3} \\
{[\%]}\end{array}$ \\
\hline 11.91 & $<0.10$ & 0.25 & 11.75 & 72.37 & $<0.10$ & 0.56 & 1.95 & $<0.10$ & $<0.10$ & 0.83 \\
\hline
\end{tabular}

The chemical analysis indicates that the zeolite contains alumina silicates with a high content of silica and is strongly alkaline.

The following laboratory determinations were performed:

Specific gravity $=2.32 \mathrm{~g} / \mathrm{cm}^{3}$, Specific surface area $=33.56 \mathrm{~m}^{2} / \mathrm{g}$, Cation exchange capacity (CEC) $=50 \mathrm{meq} / 100 \mathrm{~g}$. Low specific surface area indicates low porosity due to low zeolitic crystallinity [20].

\section{$\mathrm{NH}_{4}^{+}, \mathrm{Zn}^{+2}$ cation exchange tests by varying time}

Cation uptake by the zeolite was calculated as the difference between the amount in the starting and final solutions. Figure No. 3, shows cation uptake for each of the ions examined, expressed as milligrams per gram of zeolite versus contact time.

Figure 3 clearly reveals that after roughly 20 hours in the operating conditions the amount of cation exchanged remains practically constant. Thus, in subsequent characterization tests, in line with experiments reported in the literature, the contact time between the zeolite material and the cation containing solutions was set at 24 hours to ensure the steady-state condition [21].

\section{Tests by varying cation concentrations in the starting solution}

Tests were performed following the above described procedures and for a contact time of 24 hours on the untreated and Na-exchanged material and using solutions containing different cation concentrations, examined singly. Figures No. 4, 5 and 6 show the $\mathrm{NH}_{4}{ }^{+}, \mathrm{Pb}^{+2}, \mathrm{Cd}^{+2}, \mathrm{Cu}^{+2}, \mathrm{Zn}^{+2}$ and $\mathrm{Mn}^{+2}$ uptake respectively for the untreated and Na-

Downloadable from: Revista Boliviana 
REVISTA BOLIVIANA DE QUÍMICA

ISSN 0250-5460 Rev. Bol. Quim. Paper edition

ISSN 2078-3949 Rev, boliv, quim. Electronic edition

Marcelo Rodríguez Valdivia et al. RBQ Vol.38, No.2, pp. 95-103, 2021

exchanged material, expressed as milligrams per g of zeolite, and as percentage with respect to the starting solution, versus cation content in the starting solution $(\mathrm{mg} / \mathrm{L})$

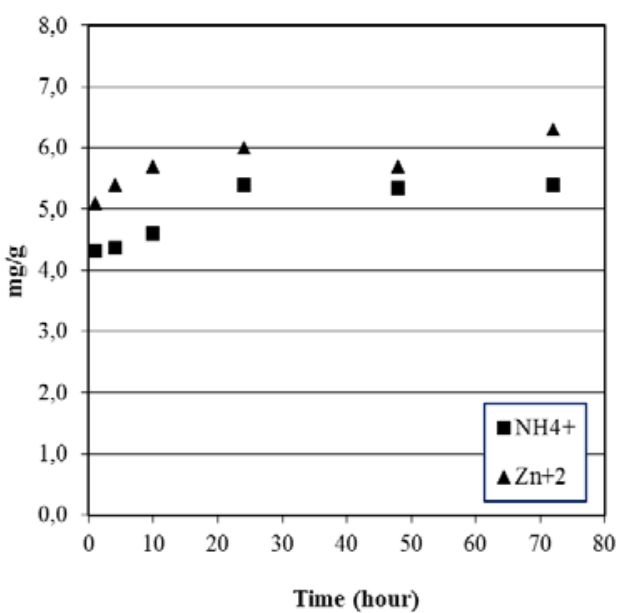

Figure No. 3. $\mathrm{NH}_{4}{ }^{+}$and $\mathrm{Zn}^{+2}$ uptake (mg per $\mathrm{g}$ of zeolite material) versus time

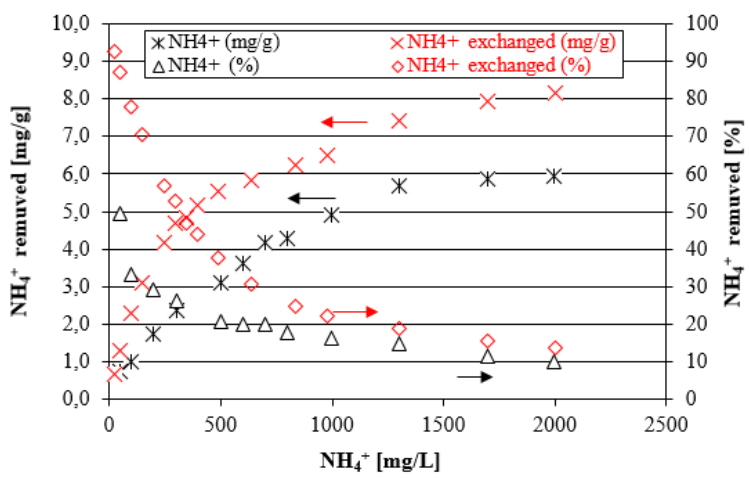

(a)

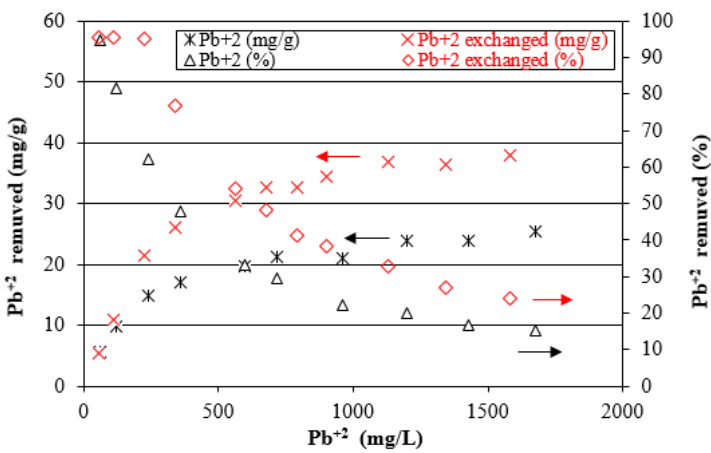

(b)

Figure No. 4. Uptake by untreated and Na-exchanged zeolite: (a) $\mathrm{NH}_{4}{ }^{+}$and (b) $\mathrm{Pb}^{+2}$

\section{Correlation of experimental data with the Freundlich and Langmuir isotherms}

Tables No. 2 and 3 show for the untreated and Na-exchanged zeolite material respectively the values of the Freundlich and Langmuir isotherm constants and the corresponding correlation coefficients $(\mathrm{R})$ for the experimental equilibrium values.

Table No. 2. Untreated zeolite material. Values of Freundlich and Langmuir isotherm constants and corresponding correlation coefficients $(R)$ for experimental equilibrium values

\begin{tabular}{ccccccc}
\hline Test & \multicolumn{3}{c}{ Freundlich } & \multicolumn{3}{c}{ Langmuir } \\
& $\mathbf{k}$ & $\mathbf{n}$ & $\mathbf{R}$ & $\mathbf{X}_{\mathbf{m}}$ & $\mathbf{b}$ & $\mathbf{R}$ \\
\hline $\mathbf{N H}_{\mathbf{4}}{ }^{+}$ & 0.125 & 1.864 & 0.967 & 4.486 & 0.007 & $\mathbf{0 . 6 3 5}$ \\
$\mathbf{P b}^{+2}$ & 4.622 & 4.182 & 0.991 & 19.503 & 0.123 & $\mathbf{0 . 7 8 5}$ \\
$\mathbf{C d}^{+2}$ & 0.840 & 2.457 & 0.927 & 6.6189 & 0.099 & $\mathbf{0 . 6 7 1}$ \\
$\mathbf{C u}^{+2}$ & 0.975 & 3.226 & 0.983 & 5.700 & 0.074 & $\mathbf{0 . 8 4 5}$ \\
$\mathbf{Z n}$ & 0.577 & 2.823 & 0.996 & 4.817 & 0.0347 & $\mathbf{0 . 7 9 1}$ \\
$\mathbf{M n}^{+2}$ & $\mathbf{0 . 5 8 8}$ & $\mathbf{2 . 8 9 0}$ & $\mathbf{0 . 9 8 6}$ & $\mathbf{3 . 8 5 4}$ & $\mathbf{0 . 0 9 3 4}$ & $\mathbf{0 . 6 2 8}$ \\
\hline
\end{tabular}

Downloadable from: Revista Boliviana 
REVISTA BOLIVIANA DE QUÍMICA

ISSN 0250-5460 Rev. Bol. Quim. Paper edition

ISSN 2078-3949 Rev. boliv. quim. Electronic edition

Marcelo Rodríguez Valdivia et al. RBQ Vol.38, No.2, pp. 95-103, 2021

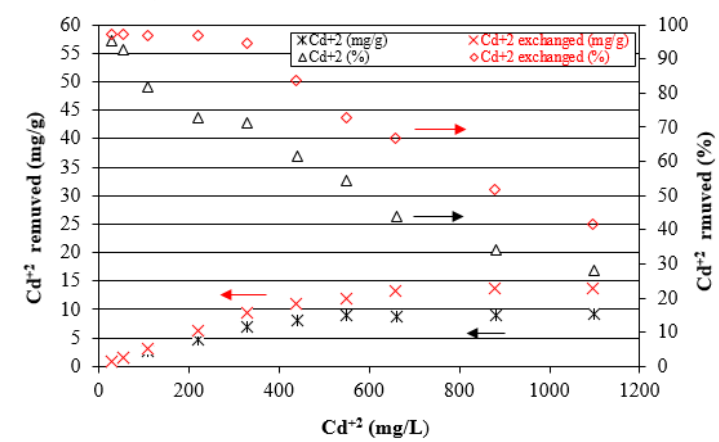

(c)

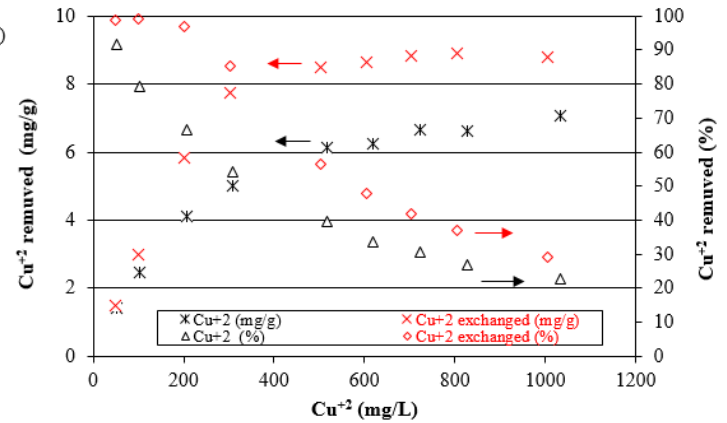

Figure No. 5. Uptake by untreated and Na-exchanged zeolite: (c) $\mathrm{Cd}^{+2}$ and (d) $\mathrm{Cu}^{+2}$
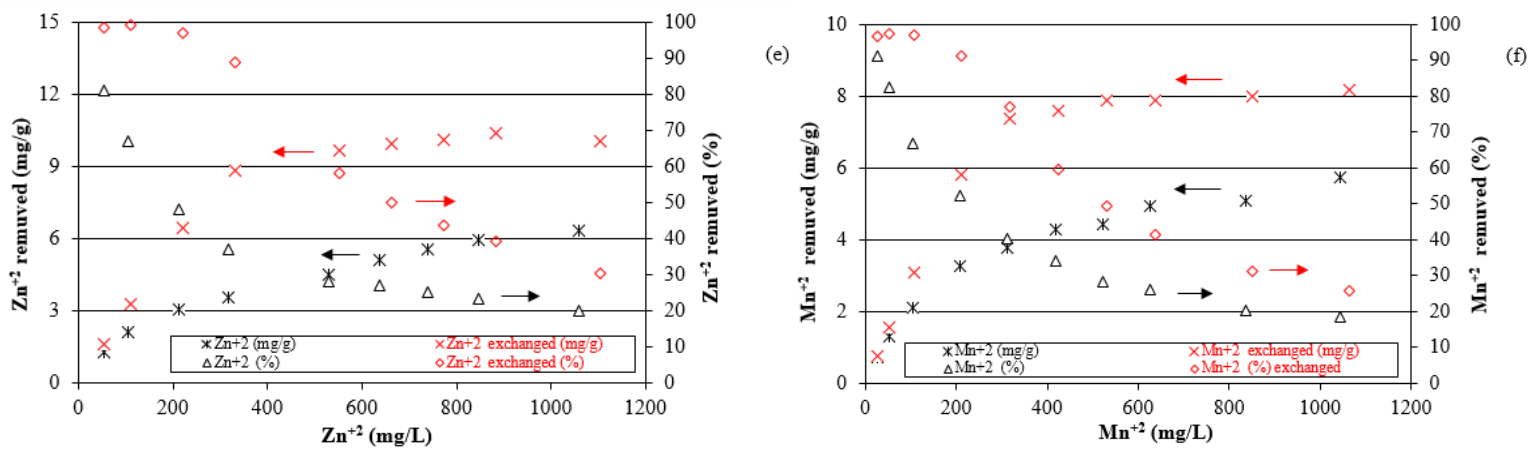

Figure No. 6. Uptake by untreated and Na-exchanged zeolite: (e) $\mathrm{Zn}^{+2}$ and (f) $\mathrm{Mn}^{+2}$

Table No. 3. Na-exchanged zeolite material. Values of Freundlich and Langmuir isotherm constants and corresponding correlation coefficients $(R)$ for experimental equilibrium values

\begin{tabular}{ccccccc}
\hline Test & \multicolumn{3}{c}{ Freundlich } & \multicolumn{3}{c}{ Langmuir } \\
& $\mathbf{k}$ & $\mathbf{n}$ & $\mathbf{R}$ & $\mathbf{X}_{\mathbf{m}}$ & $\mathbf{b}$ & $\mathbf{R}$ \\
\hline $\mathbf{N H}_{4}{ }^{+}$ & 0.725 & 2.902 & 0.975 & 5.132 & 0.081 & $\mathbf{0 . 7 2 2}$ \\
$\mathbf{P b}^{+2}$ & 7.027 & 3.922 & 0.942 & 37.068 & 0.072 & $\mathbf{0 . 9 4 5}$ \\
$\mathbf{C d}^{+2}$ & 1.724 & 2.620 & 0.894 & 15.611 & 0.072 & $\mathbf{0 . 9 6 5}$ \\
$\mathbf{C u}{ }^{+2}$ & 2.689 & 4.837 & 0.934 & 8.896 & 0.386 & $\mathbf{0 . 9 8 8}$ \\
$\mathbf{Z n}$ & 2.882 & 4.623 & 0.928 & 10.382 & 0.273 & $\mathbf{0 . 9 9 0}$ \\
$\mathbf{M n}^{+2}$ & $\mathbf{1 . 5 1 2}$ & $\mathbf{3 . 3 9 2}$ & $\mathbf{0 . 8 9 7}$ & $\mathbf{9 . 5 2 4}$ & $\mathbf{0 . 1 1 0}$ & $\mathbf{0 . 9 4 1}$ \\
\hline
\end{tabular}

Examination of the results obtained for the ion exchange tests on the untreated material with size class in the $5+0.7 \mathrm{~mm}$ range using solutions containing the single cations examined reveals that: The exchange equilibrium relationships are well described by the Freundlich isotherm. It can be seen that the values of R, are close to unity and that the values of $n$ are greater than 2, which indicates a favorable adsorption process on the surface of the zeolite [22].

The selectivity of the zeolitic material towards the cations examined differs in the order: $\mathrm{Pb}^{+2}>\mathrm{Cd}^{+2}>\mathrm{Cu}^{+2}>$ $\mathrm{Zn}^{+2}>\mathrm{Mn}^{+2}>\mathrm{NH}_{4}^{+}$, in agreement with the findings reported by other researchers for metallic ions. Zamzow [23] (cited by Kraljevic Pavelic [24, p.2]) aligned the selectivity of clinoptilolite zeolite as follows: $\mathrm{Pb}^{+2}>\mathrm{Cd}^{+2}>\mathrm{Cs}^{+}>$ $\mathrm{Cu}^{+2}>\mathrm{Co}^{+2}>\mathrm{Cr}^{+3}>\mathrm{Zn}^{+2}>\mathrm{Ni}^{+2}>\mathrm{Hg}^{+2}$. This depends on the fact that adsorption phenomena are influenced by charge 
density as well as by hydration energy and ionic radius of the cations.

For the metal ions examined here, exchange capacity decreases with ionic radius, greater exchange capacity corresponding to greater ionic radius $\left(\mathrm{Pb}^{+2}\right)$. Charge density being equal, the smaller ions $\left(\mathrm{Mn}^{+2}\right)$ exhibit higher electric charge as they hydrate more readily, encountering greater difficulty in penetrating the zeolite pores to reach the available exchange sites. Note that exchange capacity towards $\mathrm{NH}_{4}{ }^{+}$, though not negligible, is inferior not only for $\mathrm{Pb}^{+2}$, as occurs for other zeolitic materials, but also to the other metal ions examined. Presumably the significant amounts of clay contained in the zeolitic material tested here contribute to uptake of the metal ions examined.

For the material Na-exchanged with a $2 \mathrm{~N} \mathrm{NaCl}$ solution, the results obtained show that: The metal cation exchange equilibrium relationships are better described by the Langmuir isotherm than by the Freundlich isotherm and denotes that adsorption is multilayer and that there is surface heterogeneity in the adsorbent [25].

This can be explained by the fact that during pretreatment of the zeolite material with a strongly alkaline solution $(2 \mathrm{~N} \mathrm{NaCl}$ ) the ions present are replaced by $\mathrm{Na}$ in the exchange sites. Subsequently, when the Na-exchanged material comes into contact with solutions containing bivalent metal cations, exchange occurs more readily with $\mathrm{Na}$ and greater exchange capacity is achieved for lower cation concentrations in the starting solution. Only for $\mathrm{NH}_{4}{ }^{+}$did the Freundlich isotherm provide a better correlation with the experimental results. For this cation, the selectivity of the zeolite is strong due to the lower hydrated ionic radius that it presents. Petrous [26] (cited by Santiago [27, p. 14]) confirmed that selectivity of clinoptilolite is higher for $\mathrm{NH}_{4}{ }^{+}$due to its lower hydrated radius ion $3.3 \AA$. Similarly to the untreated zeolitic material, the Na-exchanged zeolite also exhibits different selectivity in the order: $\mathrm{Pb}^{+2}>\mathrm{Cd}^{+2}>$ $\mathrm{Zn}^{+2}>\mathrm{Cu}^{+2}>\mathrm{Mn}^{+2}>\mathrm{NH}_{4}^{+}$, though in this case the positions of $\mathrm{Cu}^{+2}$ and $\mathrm{Zn}^{+2}$ are inverted. Further investigation is warranted to explain this behavior, which can presumably be attributed to changes in the properties of the Naexchanged material. Under the same operating conditions, the Na-exchanged material proved to be more effective in removing the cations than the untreated material. As an example, for a cation concentration of $1000 \mathrm{mg} / \mathrm{L}$ in the feed solution, uptake by the Na-exchanged material was 32\%, 55\%, 47\%, 25\%, 53\% and 42\% higher for $\mathrm{NH}_{4}{ }^{+}, \mathrm{Pb}^{+2}$, $\mathrm{Cd}^{+2}, \mathrm{Cu}^{+2}, \mathrm{Zn}^{+2}$ and $\mathrm{Mn}^{+2}$ respectively than the untreated material. The improvement of the Na-exchanged removal capacity can be explained by the enrichment of $\mathrm{Na}^{+}$cations on the natural material and create new available sites and that are accessible for incoming cations [27].

\section{CONCLUSIONS}

The mineralogical investigation carried out on a sample of zeolite material, revealed the presence of zeolite minerals such as heulandite and mordenite along with smectite, quartz, cristobalite and feldspar.

Laboratory tests showed the material to exhibit good cation exchange capacity towards the ions examined in the order: $\mathrm{Pb}^{+2}>\mathrm{Cd}^{+2}>\mathrm{Cu}^{+2}>\mathrm{Zn}^{+2}>\mathrm{Mn}^{+2}>\mathrm{NH}_{4}{ }^{+}$. Pre-treating the material with a NaCl solution significantly increases the adsorption capacity for all the tested ions. In light of the encouraging results obtained and the need to extend the investigation to representative samples of the area as a whole, it is recommended that prospection be continued so as to determine more accurately the actual size and characteristics of the deposit with a view to its industrial exploitation.

\section{ACKNOWLEDGMENTS}

The authors acknowledge to the Faculty of Geoengineering an Environmental Technologies at the University of Cagliari-Italy. Dr. Antonio Zucca is acknowledged for his professional support in the development of this research.

\section{REFERENCES}

1. Tasic, Z.Z., Bogdanovic, G.D., Antonijevic, M.M. 2019, Application of Natural Zeolite in Wastewater Treatment - A Review, Journal of Mining and Metallurgy, 55A(1), 67-69. DOI: https://doi.org/10.5937/JMMA1901067T

2. Moshoeshoe, M., Tabbiruka, M., Obuseng, V. 2017, A review of the Chemistry, Structure, Properties and Applications of zeolites, American Journal of Materials Science, 7(5), 196-221. DOI: https://doi.org/10.5923/j.materials.20170705.12

3. Schneider, A., Zimmermann, O., Gewehr, C. 2017, Zeolites in poultry and swine production, Ciencia Rural, Santa María., 47(8), 1-8. DOI: https://dx.doi.org/10.1590/0103-8478cr20160344

4. Wang, S., Peng, Y. 2010, Natural zeolites as effective adsorbents in water and wastewater treatment, Chemical Engineering Journal, 156, 11-24. DOI: https://doi.org/10.1016/j.cej.2009.10.029 
5. Ciosek, A.L., Luk, G.K. 2018, Effects of Operation Parameters on Heavy Metallic Ion Removal from Mine Waste by Natural Zeolite, International Journal of Environmental Pollution and Remediation (IJEPR), 6, 10-24. DOI: https://dx.doi.org/10.11159/ijepr.2018.002

6. Kragovi, M., Dakovi, A., Milicevic, S. Sekuli, Z. 2012, Removal of lead from aqueous solutions by using the natural and Fe(III)modified zeolite, Appl. Surf. Sci., 258(8), 3667-3673. DOI: https://dx.doi.org/10.1016/j.apsusc.2011.12.002

7. Shi, J., Yang, Z., Dai, H., Lu, X., Peng, L., Tan, X., Shi, L., Fahim, R. 2018, Preparation and application of modified zeolites as adsorbents in wastewater treatment, Water Science \& Technology, 2017(3), 621-635. DOI: https://dx.doi.org/10.2166/wst.2018.249

8. Kotoulas, A., Agathou, D., Triantaphyllidou, I.E., Tatoulis, T.I. Akratos, C.S. Tekerlekopoulou, A.G., Vayenas, D.V. 2019, Zeolite as a Potential Medium for Ammonium Recovery and Second Cheese Whey Treatment, Water, 11(136), 1-23. DOI: https://doi.org/10.3390/w11010136

9. Ferretti, G., Galamini, G., Medoro, V., Coltorti, M., Di Giuseppe, D., Faccini, B. 2020, Impact of Sequential Treatments with Natural and Na-Exchanged Chabazite Zeolite-Rich Tuff on Pig-Slurry Chemical Composition, Water, 12(310), 2-20. DOI: https://dx.doi.org/10.3390/w12020310

10. Belova, T.P. 2019, Adsorption of heavy metal ions $\left(\mathrm{Cu}^{2+}, \mathrm{Ni}^{2+}, \mathrm{Co}^{2+}\right.$ and $\left.\mathrm{Fe}^{2+}\right)$ from aqueous solutions by natural zeolite, Heliyon, 5(9) e02320. DOI: https://doi.org/10.1016/j.heliyon.2019.e02320

11. Abatal, M., Olguin, M., Abdellaoui, Y., Bouari, A. 2018, Sorption of Cd (II), Ni (II) and Zn (II) on Natural, Sodium-and Acid-Modified Clinoptilolite-Rich Tuff, Environment Protection Engineering, 44(1), 41-59. DOI: https://dx.doi.org/10.5277/epe180104

12. El-Azim, H.A., Mourad, F.A. 2018, Removal of Heavy Metals Cd (II), Fe (III) and Ni (II), from Aqueous Solutions by Natural (Clinoptilolite) Zeolites and Application to Industrial Wastewater, Asian Journal of Environment \& Ecology, 7(1), 1-13. DOI: https://dx.doi.org/10.9734/AJEE/2018/41004

13. Golomeova, M., Zendelska, A. Application of Some Natural Porous Raw Materials for Removal of Lead and Zinc from Aqueous Solutions, In: Microporous and Mesoporous Materials, ed by Reza Sabet Dariani, 2016, Ed. Rijeka, Croatia, 21-49. DOI: $10.5772 / 62347$

14. Kujawska, J., Wasag, H. 2019, Reduction of excessive heavy metals accumulation in drinking water with natural zeolites, Materials Science and Engineering, 710, 1-8. DOI: https://dx.doi.org/10.1088/1757-899X/710/1/012033

15. Stocker, K., Ellersdorfer, M., Lehner, M., Raith, J.G. 2017, Characterization and Utilization of Natural Zeolites in Technical Applications, BMH, 162(4), 142-147. DOI: https://dx.doi.org/10.1007/s00501-017-0596-5

16. Malamis, S., E. Katsou, E. 2013, A review on zinc and nickel adsorption on natural and modified zeolite, bentonite and vermiculite: Examination of process parameters, kinetics and isotherms, Journal of Hazardous Materials, 252-253, 428-461. DOI: https://dx.doi.org/10.1016/j.jhazmat.2013.03.024

17. Carbonel, D., 2018, Cadmium, Copper and Lead Adsorption on Natural and Modified Bentonite, Kaolin and Zeolite: A Review of Process Parameters, Isotherms and Kinetics, Revista Ingeniería, 23(3), 252-273. DOI: https://dx.doi.org/10.14483/23448393.13418

18. Khayyun, T.S., Mseer, A.H, 2019, Comparison of the experimental results with the Langmuir and Freundlich models for copper removal on limestone adsorbent, Applied Water Science, 9(170), 161-168. DOI: https://dx.doi.org/10.1007/s13201-019-1061-2 